\title{
Leaf area estimation of Anacardium humile
}

\author{
Francielly Rodrigues Gomes ${ }^{1}$, Danielle Fabíola Pereira da Silva ${ }^{2}$, \\ Angelita Lorrayne Soares Lima Ragagnin ${ }^{3}$, Pedro Henrique Magalhães de Souza ${ }^{4}$, \\ Simério Carlos Silva Cruz
}

\begin{abstract}
The Anacardium humile A. St.- Hil. fruit tree has productive potential, being their fruits appreciated in the Cerrado region for having characteristic flavor, however, this species is still exploited in an extractive way, being necessary studies for its domestication. The aim of this work was to estimate the leaf area of Anacardium humile. One hundred leaves were collected in the biological collection from a genetic resources field and evaluated for length, width and fresh weight, and scanned at resolution of 300 dpi to determine the leaf area with the aid of the ImageJ image analysis program. Subsequently, a leaf disc with a diameter of $22.27 \mathrm{~mm}$ was detached at the basal portion of each leaf, in which the fresh weight of the discs was obtained. Data were submitted to descriptive analysis and the relationship among the features explained by Pearson's correlation with the software Rbio. The data were also subjected to regression analysis to explain the relationship between leaf area and measurements of width, length and leaf weight, and to fit the proper statistical model with the software Origin. It was concluded that leaf area can be determined by image analysis software and linear measurements are correlated to leaf area.
\end{abstract}

Index terms: Cajuzinho-do-cerrado, native fruits, species conservation.

\section{Estimativa da área foliar de Anacardium humile}

Corresponding author:

fram_rodgomes@hotmail.com

Received: April 03, 2020

Accepted: June 19, 2020

Copyright: All the contents of this journal, except where otherwise noted, is licensed under a Creative Commons Attribution License.
Resumo - As plantas de Anacardium humile A. St.- Hil. (cajuzinho-do-cerrado) possuem potencial produtivo, sendo seus frutos apreciados na região do Cerrado por apresentarem sabor característico; no entanto, esta espécie ainda é explorada de forma extrativista, fazendo com que sejam necessários estudos que objetivem sua domesticação. O objetivo do presente trabalho foi estimar a área foliar de plantas de Anacardium humile. As folhas foram coletadas na coleção biológica de um campo de recursos genéticos e avaliadas quanto ao comprimento, largura e massa fresca, e foram escaneadas na resolução de 300 dpi para determinar da área foliar com auxílio do programa de análise de imagens ImageJ. Posteriormente, foi destacado um disco foliar na porção basal de cada folha com o auxílio de um vazador de $22,27 \mathrm{~mm}$, no qual se obteve a massa fresca dos discos. Os dados foram submetidos à análise descritiva, e a relação entre as características, explicadas pela correlação de Pearson no programa Rbio. Os dados foram ainda submetidos a analises de regressão para explicar a relação entre a área foliar e as medidas de comprimento, largura e peso das folhas, e para ajustar o modelo matemático adequado com o software Origin. Concluiu-se que a área foliar pode ser determinada por programas de análises de imagens e que as medidas lineares se relacionam com a área foliar. Termos para indexação: Cajuzinho-do-cerrado, Fruteiras nativas, conservação das espécies.

\section{$(\mathrm{cc}) \mathbf{E Y}$}

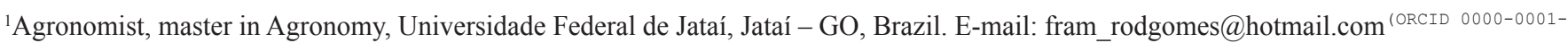
7282-0719)

${ }^{2}$ Agronomist, $\mathrm{PhD}$ in Plant Science, professor at Universidade Federal de Jataí, Academic department of agrarian sciences, Jataí - GO, Brazil.

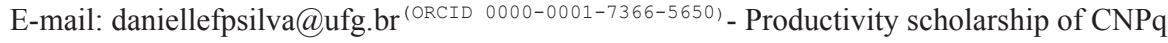

${ }^{3}$ Agronomist, master's degree student at Programa de Pós-graduação em Agronomia, Universidade Federal de Jataí, Jataí - GO, Brazil. E-mail: angelitaragagnin@gmail.com (scholarship of CNPq) (ORCID 0000-0002-5115-2704)

${ }^{4}$ Agronomist, master's degree student at Programa de Pós-graduação em Agronomia, Universidade Federal de Jataí, Jataí - GO, Brazil. E-mail: pedrrromagalhaes@gmail.com (scholarship of CAPES)(ORCID 0000-0002-4824-0738)

${ }^{5}$ Agronomist, $\mathrm{PhD}$ in Agronomy, professor at Universidade Federal de Jataí, Academic department of agrarian sciences, Jataí - GO, Brazil. E-mail: simerio_cruz@yahoo.com.br ${ }^{(O R C I D}$ 0000-0002-6327-8590)
} 


\section{Introduction}

The Cerrado is the second largest Brazilian biome, standing out as one of the richest in the world for having species with pharmaceutical and food potential (LIMA; PORTARI, 2019). It can be found in Goiás, Mato Grosso, Tocantins, Mato Grosso do Sul, Minas Gerais, Rondônia, São Paulo, Distrito Federal and some parts of Piauí, Bahia and Maranhão (REIS; SCHIMIELE, 2019), with area of approximately 2 million $\mathrm{km}^{2}$, which represents almost $25 \%$ of the national territory (DURIGAN; RATTER, 2016). This biome presents predominantly seasonal tropical climatic conditions with rainfall of approximately 1500 $\mathrm{mm}$, which is favorable for the development of attractive species for exploitation, research and marketing, and these species are characterized by having high nutritional value, characteristic flavor and aroma, and healthy appeal (REIS; SCHMIELE, 2019).

Among these species there is the A. humile, which is widely distributed, especially in the Brazilian Midwest region, and produces fruits that are used in extractive way by the regional population and employed in the manufacture of food, juices, medicines and cosmetics (RESSEL et al., 2015). These fruits have great acceptance by the local population, because they have peculiar organoleptic characteristics and high potential for sustainable production (CARVALHO et al., 2012).

The literature reports many works with the genus Anacardium, but fewer referring to the A. humile. Due to this lack of studies, there are many possibilities for the beginning of research on the development of the species, in order to plan future strategies for this species preservation and use. Studies with wild species are an important alternative for incorporating them into the commercial chain (CARVALHO et al., 2005; ATAÍDE et al., 2012).

Besides the great potential of this fruit species due to its high vitamin $\mathrm{C}$ content, the leaves are also widely used in common medicine as expectorant (FERREIRA et al., 2012; PEREIRA et al., 2019; MUIANGA et al., 2016). It has been reported that these leaves have insecticidal, anti-inflammatory, antimicrobial and antioxidant properties (ANDRADE FILHO et al., 2010).

Also known popularly as "Cajuzinho-do-cerrado", this species is a hermaphroditic subshrub with flowering from June to November and fruiting from October to November, the peduncle is very appreciated in Cerrado regions and it can be consumed fresh or processed (SANTOS; SANTOS JUNIOR, 2015). The $A$. humile tree is a perennial species, which has a small plant with leathery leaves and terminal inflorescence (LORENZI, 2006; SILVA-LUZ; PIRANI, 2010). Its leaves are alternate, the adaxial face presents flat and glabrous surface, while the abaxial face presents glabrous to glabrescent surface with prominent nerve (RESSEL et al., 2015).
It is known that the leaf is the main organ responsible for water loss and gas exchange between the plant and the environment, also, is where the photosynthetic process occurs, which depends on the absorption of light energy and its conversion to chemical energy. The knowledge about plants metabolism and growth can be obtained through leaf area analysis (MORGADO et al., 2013; PADRÓN et al., 2016), which can assist cultural treatments such as pruning, fertilization and planting density (TOEBE et al., 2019).

Evaluation by leaf dimension is one of the most used techniques because it has low cost, requiring only the use of a graduated ruler or similar, and because it has good accuracy (SILVA et al., 2015). Another viable alternative is the use of digitalized images in software capable of processing the images and calculating the leaf area (LUCENA et al., 2011).

According to Lima et al. (2019), Anacardium species are rustic and widely adapted to the climatic conditions of Brazil, especially the northeast region, however, they present significant losses caused by diseases. The occurrence of diseases leads to reduction of leaf area, which affects photosynthetic efficiency and photosynthesis accumulation (FIALLOS; FORCELINI, 2011).

Since the study of leaf area is essential to the knowledge of species propagation and management techniques, being essential to evaluate vegetative growth and development (RIBEIRO et al., 2018) and the A. humile has high nutritional and productive potential, but consists of an undomesticated species due to the lack of studies on it (RESSEL et al., 2015), the aim of this work was to estimate the leaf area of $A$. humile by image analysis.

\section{Material and Methods}

The work was carried out on summer in a region classified as tropical rainy (Aw) according to the Köppen's classification, with an average annual temperature from 18 to $32{ }^{\circ} \mathrm{C}$ and average annual rainfall of $1700 \mathrm{~mm}$. The A. humile leaves evaluated were selected in the collection of the field of genetic resources with 542 plants cultivated from seeds, which were obtained in fourteen municipalities.

Within the plants located in the biological collection, one hundred leaves were harvested from the median portion of the plants, following the methodology adopted by Lemos et al. (2010). These leaves were placed into plastic bags and sent to laboratory where they were evaluated for length and width with the aid of a digital caliper, which the results were given in $\mathrm{mm}$, and leaf weight obtained in a weighing machine with results given in grams. 
After the evaluation of measurements and weight, the one hundred leaves were scanned individually at resolution of $300 \mathrm{dpi}$ and processed aiming determinate leaf area with the aid of image analysis software, and these results were given in $\mathrm{cm}^{2}$ (Figure 1). Posteriorly, discs with $22.27 \mathrm{~mm}$ were detached from the base of each leaf. All discs were evaluated for the weight with the aid of a weighing machine and the results were expressed in grams.

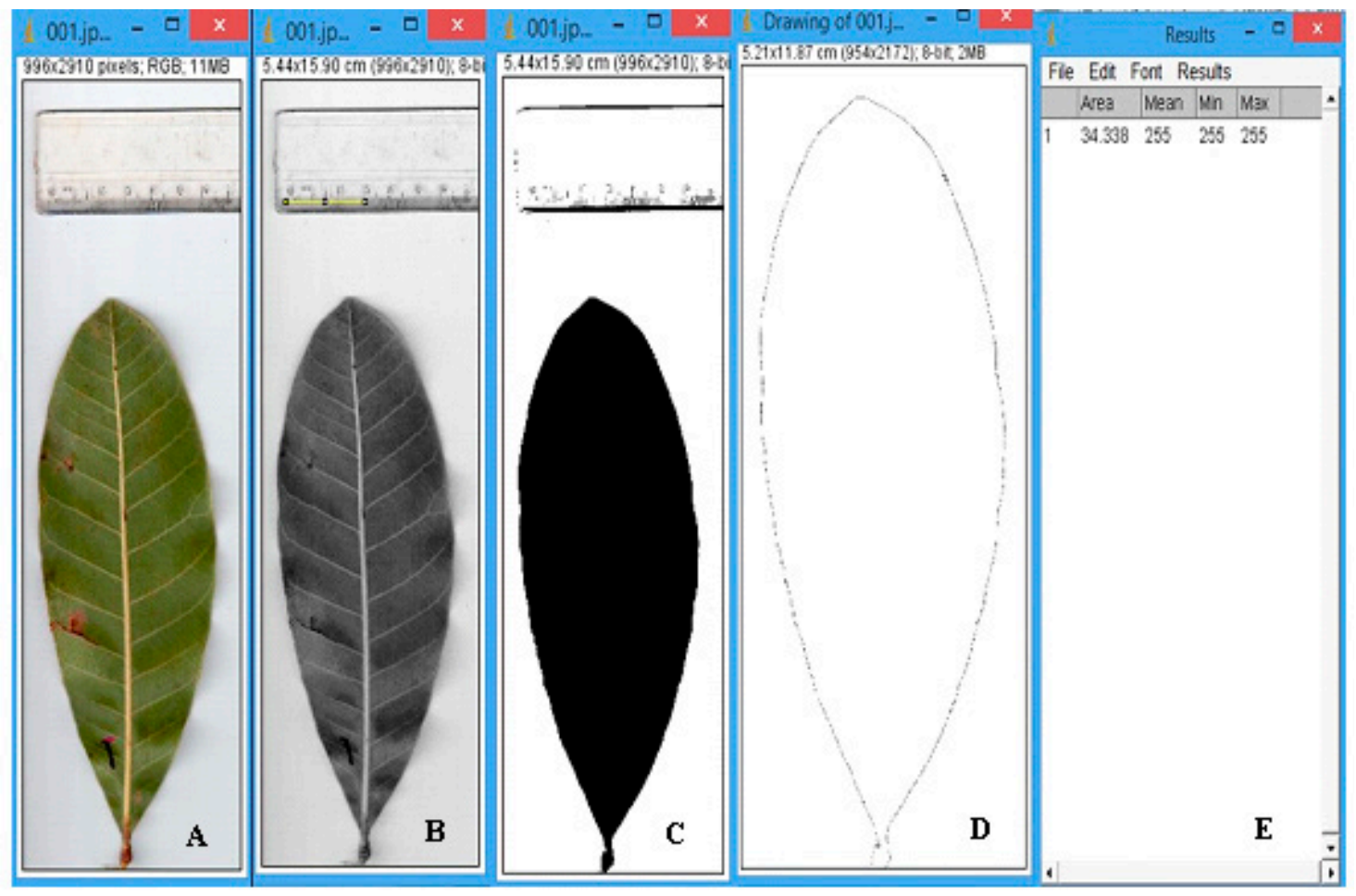

Figure 1. Scanned leaf of A. humile for the processing in ImageJ (A and B), black and white leaf surface for contrast (C), drawing of the leaf surface (D) and the leaf area in $\mathrm{cm}^{2}(\mathrm{E})$.

The data were treated as completely randomized design, submitted to descriptive analysis and in order to determine the relationship among the features of length, width, weight of discs and leaves and leaf area, was performed the Pearson's correlation at significance level of 1 and $5 \%$. The data were also subjected to regression analysis to explain the relationship between leaf area and measurements of length, width and leaf weight and to fit the proper statistical model. Data of length, width, fresh weight and leaf area were analyzed using Rbio statistical software (BHERING, 2017), the adjustment of the models and the graphics were plotted in Origin 8.5.1 SR1, and leaf area was determined by imageJ software.

\section{Results and Discussion}

The leaves of the $A$. humile had average leaf area of $66.68 \mathrm{~cm}^{2}$, and it is possible to observe that there was great variation among the leaves, with leaf area varying approximately between 24 and $127 \mathrm{~cm}^{2}$ (Table 1). Due to the genetic variability that occurs in A. humile, plants are highly divergent from the fruits to the size of the plants (SANTOS et al., 2020), which leads to variation in the size of their leaves.

Table 1. Descriptive analysis of features from one hundred leaves of A. humile

\begin{tabular}{cccccc}
\hline & $\mathrm{LA}^{/ 1}\left(\mathrm{~cm}^{2}\right)$ & $\mathrm{W}(\mathrm{mm})$ & $\mathrm{L}(\mathrm{mm})$ & $\mathrm{LW}(\mathrm{g})$ & $\mathrm{DW}(\mathrm{g})$ \\
\hline Average & 66.68 & 60.31 & 145.85 & 1.86 & 0.10 \\
Minimum & 24.94 & 36.54 & 84.46 & 0.72 & 0.01 \\
Maximum & 127.5 & 104.97 & 204.80 & 4.08 & 0.18 \\
Standard deviation & 22.04 & 13.72 & 24.28 & 0.72 & 0.03 \\
CV (\%) & 33.05 & 22.74 & 16.65 & 38.68 & 33.60 \\
\hline
\end{tabular}

${ }^{11}$ LA: Leaf Area, W: Width, L: Length, LW: Leaf weight, DW: Disc weight. 
Knowledge of leaf area is important, regardless of culture, because this characteristic represents the light interception by the photosynthetic apparatus and is widely used to determine vegetative growth (SANTOS et al., 2014; FERREIRA et al., 2017). The maximum light interception through the leaf area varies for each crop; however, a larger leaf area will cause greater shading of the lower plants and a lower photosynthetic rate of plants (OLIVEIRA FILHO et al., 2018).

The processing by softwares helps to obtain images information for latter interpretations. Image analysis is efficient to determine shapes and sizes from the objects of interest and can be used in a quickly and simple way, discarding the need to use expensive devices (VIEIRA JUNIOR et al., 2006; MATOS et al., 2019). According to Shi et al. (2019), the leaf surface of a plant is the basis of the potential yield of the crop and knowledge of the leaf area of the plant allows the estimation of water loss, since the leaves are the main organs that participate in the transpiration process, responsible for gas exchange with the environment.

The width of the leaves the average was $60.31 \mathrm{~mm}$ and for the length was $145.85 \mathrm{~mm}$, regarding the leaf weight, it was observed that they had an average weight of $1.86 \mathrm{~g}$ and the leaf discs had a weight of approximately $0.10 \mathrm{~g}$ (Table 1).

According to Faleiro and Saiki (2007), larger leaves have high evapotranspiration, but with high photosynthetic efficiency. According to these authors, in regions like the Cerrado, there is a tendency for the leaves to be small, being considered an adaptive advantage of the species to avoid water loss through evapotranspiration

Similar behavior was observed by Moraes et al. (2013), in five native Cerrado species, where plants in shaded environments presented greater length and width than plants in environments with a high incidence of solar radiation, such effect can be explained by the fact that plants in sunny locations have more active metabolism with reduced leaf area and shady plants develop higher vegetative growth as a strategy to absorb more light energy.

An efficient way to evaluate vegetative growth is by the length and width variables. The use of linear leaf measurements allows the monitoring of leaf development in the field without the need to collect the leaf, implying a simple and less costly procedure, and these two characteristics are efficient in estimating leaf area (OLIVEIRA et al., 2016). According to Sachet et al. (2015), the joint analysis of these two variables allows obtaining better coefficients of determination when compared with other methods.

Several studies have been conducted regarding the influence of fresh weight on leaf area estimation, however, according to Cunha et al. (2010) few studies use the fresh leaf weight in the estimation, because it is not possible to establish a direct relationship between the weight and the leaf area. Estimation by fresh weight of leaf discs may yield results with good accuracy in some crops or low coefficient of determination and be inefficient for other crops, as it is variable according to species, one should always compare with another method and take consideration of the characteristics of the species (LUCENA et al., 2011).

Toebe et al. (2012), report that the leaf disc method was inadequate to determine the snap bean leaf area, as it was underestimated and the image analysis method was efficient because it evaluates the leaf as a whole, regardless of the weight difference between the areas.

By Pearson's correlation coefficients between the features of the leaves of A. humile, it is possible to observe that width, leaf area, length and leaf weight presented significant correlation with each other (Table 2), indicating that the leaf linear measurements are directly related to the leaf area, this behavior allows to evaluate the vegetative growth, biomass accumulation and the final plant productivity (PEZZINI et al., 2018).

Table 2. Pearson's correlation coefficients between features from one hundred leaves of A. humile

\begin{tabular}{ccccc}
\hline & $\mathrm{LA}^{\prime 1}$ & $\mathrm{~W}$ & $\mathrm{~L}$ & $\mathrm{LW}$ \\
\hline $\mathrm{W}$ & $0.88^{* *}$ & & & \\
$\mathrm{~L}$ & $0.73^{* *}$ & $0.45^{* *}$ & & \\
$\mathrm{LW}$ & $0.87^{* *}$ & $0.73^{* *}$ & $0.71^{* *}$ & \\
$\mathrm{DW}$ & $0.06^{\mathrm{NS}}$ & $-0.005^{\mathrm{NS}}$ & $0.04^{\mathrm{NS}}$ & $0.25^{*}$ \\
\hline
\end{tabular}

NS Not significant; * Significant at 5\% probability; ${ }^{* *}$ Significant at $1 \%$ probability.

${ }^{1}$ LA: Leaf Area, W: Width, L: Length, LW: Leaf weight, DW: Disc weight. 
The leaf area of $A$. humile has a positive and significant correlation with length and width $(0.73$ and 0.88 ), as well as length positively correlates with width (0.45). It can be observed that the width has a negative and non-significant correlation with the disc weight $(-0.005)$, as well as the length and leaf area (0.04 and 0.06) and that the leaf weight has a positive and significant correlation with the weight of the discs (0.25) (Table 2).

According to Kozak (2009), values below 0.2 are not significantly correlated, while values between 0.2 and 0.5 are poorly correlated, likewise values between 0.5 and 0.7 or above 0.7 constitute a strong and very strong correlation, with positive variables moving together and negative variables in opposite directions. In the present experiment, the leaf area showed a strong correlation with length and width, indicating that as one trait increases the others increase.
Leaf length, width and weight are strongly correlated with leaf area. It is known that the leaf is the organ responsible for the production of lipids, carbohydrates and proteins, being the knowledge of linear measurements and leaf area very important to understand the processes of plant development, photosynthetic potential, nutritional and water requirement (ZEIST et al., 2014).

The simple linear regression model was the most accurate to explain the relationship of the leaf area with width, length and leaf weight, and showed a high coefficient of determination $\left(\mathrm{R}^{2}\right)$ for the relationships between leaf area $x$ width, and leaf area $x$ leaf weight (Figure 2). The higher is the $\mathrm{R}^{2}$ values and the lower is the standard error of the estimate (SEE) values, the greater will be the accuracy of the model (MORGADO et al., 2013). The prediction of models can be influenced by leaves shape and their variations along the growth, which can be decisive for the development of high precision models (HARA et al., 2019).
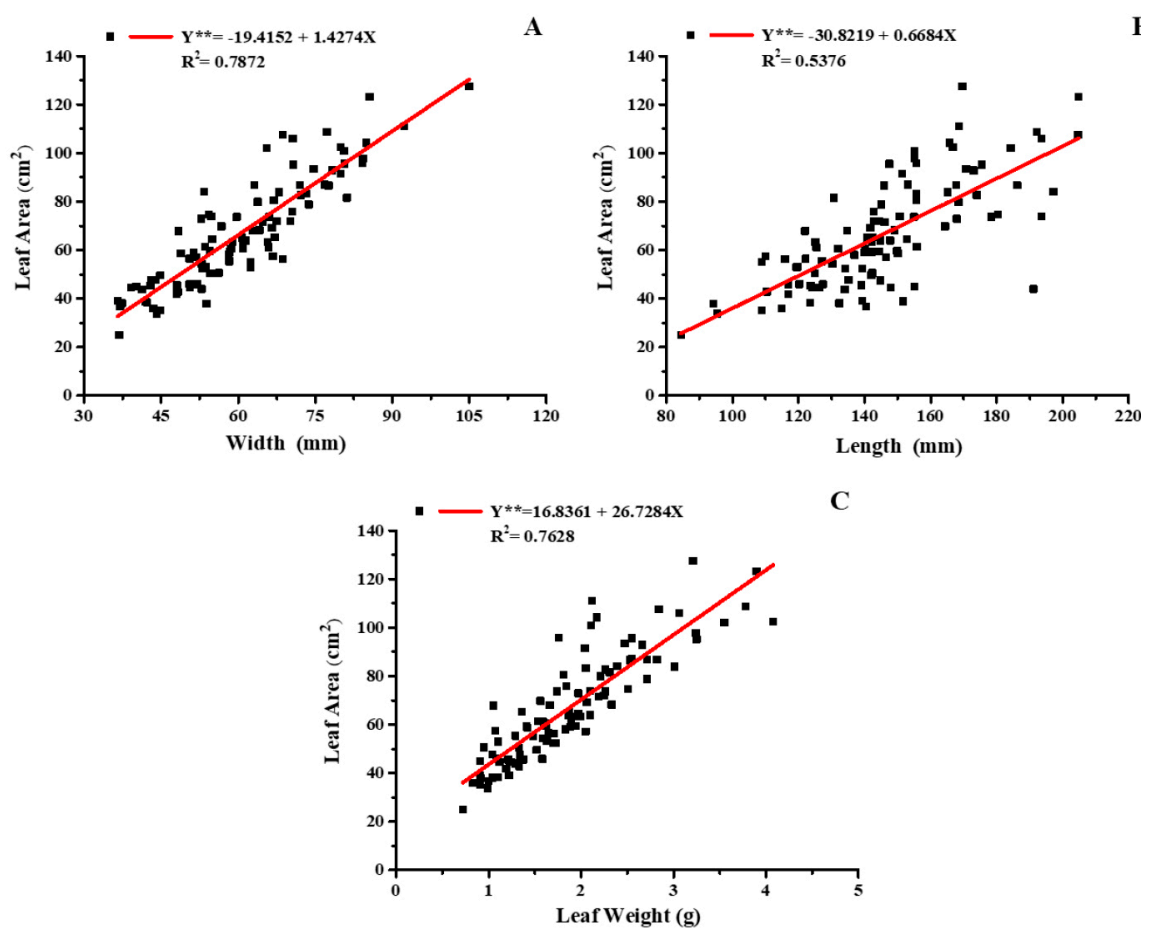

Figure 2. Relationship between leaf area and width (A); leaf area and length (B); and leaf area and leaf weight (C) of A. humile using linear regression models.

The relationship between the leaf area and the length, width and leaf weight adjusted to linear statistical model. The relationship of the leaf area $x$ leaf weight showed low SEE and high $\mathrm{R}^{2}$, while to leaf area $x$ width there was an increase in SEE and a reduction in $\mathrm{R}^{2}$ (Table $3)$. The increase in $R^{2}$ values is related to the reduction of the standard error of the estimate, which occurs due to the increase in F-calc and to the reduction of sum of the squares of the residues (FIALHO et al., 2011). 
Table 3. Statistical models, regression parameters, Standard error of estimate (SEE), Determination coefficients adjusted for degrees of freedom $\left(\mathrm{R}^{2}\right)$, F-Calculated (F-calc) and leaf area estimate (LA) as a function of linear dimensions (Width (W), Length (L)) and leaf weight (LW) of one hundred A. humile leaves

\begin{tabular}{cccccc}
\hline Model & Parameters & SEE & $\mathrm{R}^{2}$ & $\mathrm{~F}_{\text {calc }}$ & LA estimate \\
\hline $\mathrm{LA}_{\mathrm{w}}=\beta_{0}+\beta_{1} \mathrm{X}$ & $\begin{array}{c}\beta_{0}=-19.4152^{*} \\
\beta_{1}=1.4274^{*}\end{array}$ & 4.6065 & 0.7872 & $367.22^{*}$ & $\mathrm{LA}_{\mathrm{w}}=-19.4152+1.4274 \mathrm{~W}$ \\
$\mathrm{LA}_{\mathrm{l}}=\beta_{0}+\beta_{1} \mathrm{X}$ & $\begin{array}{c}\beta_{0}=-30.8220^{*} \\
\beta_{1}=0.6684^{*}\end{array}$ & 9.1704 & 0.5300 & $116.15^{*}$ & $\mathrm{LA}_{\mathrm{l}}=-30.8220+0.6684 \mathrm{~L}$ \\
$\mathrm{LA}_{\mathrm{lw}}=\beta_{0}+\beta_{1} \mathrm{X}$ & $\begin{array}{l}\beta_{0}=16.8361^{*} \\
\beta_{1}=26.7284^{*}\end{array}$ & 2.9884 & 0.7628 & $319.42^{*}$ & $\mathrm{LA}_{\mathrm{lw}}=16.8361+26.7284 \mathrm{LW}$ \\
\hline
\end{tabular}

* Significant at 5\% level.

\section{Conclusions}

The leaf area can be determined by scanning images and further processing in the image analysis software. The leaf area can be related to linear measurements.

\section{Acknowledgements}

The authors thank the Coordenação de Aperfeiçoamento de Pessoal de Nível Superior-CAPES (Coordination for the Improvement of Higher Education Personnel) and to Conselho Nacional de Desenvolvimento Científico e Tecnológico - CNPq (National Council for Scientific and Technological Development) for financial support.

\section{References}

ANDRADE FILHO, N.N.D.; ROEL, A.R.; PORTO, K.R.D.A.; SOUZA, R.O.; COELHO, R.M.; PORTELA, A. Toxicity of aqueous extract of Anacardium humile leaves on Bemisia tuberculata. Ciência Rural, Santa Maria, v.40, p.1689-1694, 2010.

ATAÍDE, E.M.; OLIVEIRA, J.C.; RUGGIERO, C. Florescimento e frutificação do maracujazeiro silvestre Passiflora setacea D.C. cultivado em Jaboticabal, SP. Revista Brasileira de Fruticultura, Jaboticabal, v.34, n.2, p.377-381, 2012.

BHERING, L.L. Rbio: A tool for biometric and statistical analysis using the r platform. Crop Breeding and Applied Biotechnology, Viçosa, v.17, p.187-190, 2017.

CARVALHO, M.P.; SANTANA, D.G.; RANAL, M.A. Emergência de plântulas de Anacardium humile a.St.-Hil (Anacardiaceae) avaliada por meio de amostras pequenas. Revista Brasileira de Botânica, São Paulo, v.28, p.627633, 2005.
CARVALHO, R.S.; PINTO, J.F.N.; REIS, E.F.; SANTOS, S.C.; DIAS, L.A.S. Variabilidade genética de cajuzinhodo-cerrado (Anacardium humile ST. Hill.) por meio de marcadores RAPD. Revista Brasileira de Fruticultura, Jaboticabal, v.34, n.1, p.227-233, 2012.

CUNHA, J.L.X.L.; NASCIMENTO, P.G.M.L.; MESQUITA, H.C.; SILVA, M.G.O.; DOMBROSKI, J.L.D.; SILVA, I.N. Comparação de métodos de área foliar em Chrysobalanus icaco L. Agropecuária Científica no Semiárido, Campina Grande, v.6, n.3, p.22-27, 2010.

DURIGAN, G.; RATTER, J.A. The need for a consistentfire policy for Cerrado conservation. Journal of Applied Ecology, London, v.53, n.1, p.11-15, 2016.

FALEIRO, W.; SAIKI, P.T.O. Morfologia foliar em cinco fitofisionomias de cerrado do Parque Estadual da Serra de Caldas Novas, GO. Revista Brasileira de Biociências, Porto Alegre, v.5, p.687-689, 2007.

FERREIRA, O.G.L.; ROSSI, F.D.; VAZ, R.Z.; FLUCK, A.C.; COSTA, O.A.D.; FARIAS, P.P. Leaf area determination by digital image analysis. Archivos de Zootecnia, Córdoba, v.66, n.256, 593-597, 2017.

FERREIRA, P.R.B.; MENDES, C.S.O.; RODRIGUES, C.G.; ROCHA, J.C.M.; ROYO, V.A.; VALÉRIO, H.M.; OLIVEIRA, D.A. Antibacterial activity tannin-rich fraction from leaves of Anacardium humile .Ciência Rural, Santa Maria, v.42, p.1861-1864, 2012.

FIALHO, G.S.; DALVI, L.P.; DALVI, N.B.C.; KUHLCAMP, K.T.; EFFEN, E.M. Predição da área foliar em abobrinha-italiana: um método não destrutivo, exato, simples, rápido e prático. Revista Brasileira de Agropecuária Sustentável, Viçosa, v.1, p.59-63, 2011.

FIALLOS, F.R.G.; FORCELINI, C.A. Progresso temporal da ferrugem e redução sobre a área foliar e os componentes do rendimento de grãos em soja. Acta Agronómica, Palmira, v.60, n.2, p.147-157, 2011. 
HARA, A.T.; GONÇALVES, A.C.A.; MALLER, A.; HASHIGUTI, H.T.; OLIVEIRA, J.M.de. Ajuste de modelo de predição de área foliar do feijoeiro em função de medidas lineares. Revista Engenharia na Agricultura - REVENG, Viçosa, v.27, n.2, p.179-186, 2019.

KOZAK, M. What is strong correlation?. Teaching Statistics, Sheffield, v.31, n.3, p.85-86, 2009.

LEMOS, E.E.P.D.; SALVADOR, T.D.L.; SANTOS, M.Q.C.D.; REZENDE, L.D.P.; SALVADOR, T.D.L.; LIMA, H.M.A. Produção de porta-enxertos em tubetes e enxertia precoce da pinheira (Annona squamosa L.). Revista Brasileira de Fruticultura, Jaboticabal, v.32, n.3, p.865-873, 2010.

LIMA, J.; MARTINS, M.; CARDOSO, J. Powdery mildew damage to the production of BRS 189 cashew plants. Revista Ceres, Viçosa, v.66, n.3, p.1-14, 2019.

LIMA, M.C.D.; PORTARI, G.V. Centesimal composition and antioxidant compounds of two fruits from the Cerrado (Brazilian Savannah). Revista Ceres, Viçosa, MG, v.66, n.1, p.41-44, 2019.

LORENZI, H.; BACHER, L.; LACERDA, M.; SARTORI, $S$. Frutas brasileiras e exóticas cultivadas: de consumo in natura. São Paulo: Instituto Plantarum de Estudos da Flora, 2006. 672 p.

LUCENA, R.R.M.DE; BATISTA, T.M.DE V.; DOMBROSKI, J.L.D.; LOPES, W.DE A.R.; RODRIGUES, G.S.DE O. Medição da área foliar de aceroleira. Revista Caatinga, Mossoró, v.24, n.2, p.4045, 2011.

MATOS, T.J.R.; RAMOS, G.Q.; MATOS, R.S.; FONSECA FILHO, H.D. Medição da área foliar de Anacardium Occidentale L. baseada em processamento digital de imagens. Scientia Amazonia, Manaus, v.8, n.1, p.11-15, 2019.

MORAES, L.; SANTOS, R.K.; WISSER, T.Z.; KRUPEK, R.A. Avaliação da área foliar a partir de medidas lineares simples de cinco espécies vegetais sob diferentes condições de luminosidade. Revista Brasileira de Biociências, Porto Alegre, v.11, n.4, p.381-387, 2013.

MORGADO, M.A.D.; BRUCKNER, C.H.; ROSADO, L.D.S.; ASSUNÇÃO, W.; SANTOS, C.E.M. dos. Estimação da área foliar por método não destrutivo, utilizando medidas lineares das folhas de espécies de Passiflora. Revista Ceres, Viçosa, MG, v.60, n.5, p.662$667,2013$.
MUIANGA, C.A.; MUNIZ, J.A.; NASCIMENTO, M.S.; FERNANDES, T.J.; SAVIAN, T.V. Descrição da curva de crescimento de frutos do cajueiro por modelos não lineares. Revista Brasileira de Fruticultura, Jaboticabal, v.38, n.1, p.22-32, 2016.

OLIVEIRA FILHO, A.F.D.; SILVA, M.N.C.; INNECCO, R.; BEZERRA, F.T.C.; ABREU, W.E.D. Efeito do arranjo de plantio da quinoa em baixa altitude. Revista de Ciências Agrárias, Lisboa v.41, n.2, p.81-90, 2018.

OLIVEIRA, R.L.L.; MOREIRA, A.R.; COSTA, A.V.A.; SOUZA, L.C.; LIMA, L.G.S.; SILVA, R.T.L. Modelos de determinação não destrutiva de área foliar de feijão caupi Vigna unguiculata (L.). Global Science and Technology, Rio Verde, v.8, n.2, p.17-27, 2016.

PADRÓN, R.A.R.; LOPES, S.J.; SWAROWSKY, A.; CERQUERA, R.R.; NOGUEIRA, C.U.; MAFFEI, M. Non-destructive models to estimate leaf área on Bell pepper crop. Ciência Rural, Santa Maria, v.46, n.11, p.1983-1944, 2016.

PEREIRA, L.D.; SILVA, D.F.; REIS, E.F.; PINTO, J.F.; ASSUNÇÃO, H.F.; MACHADO, C.G.; GOMES, F.R.; CARNEIRO, L.C.; CRUZ, S.C.S.; COSTA, C.H.M. Characterization of Bushy Cashew (Anacardium humile A.St.-Hil.) in the State of Goiás, Brazil. Journal of Agricultural Science, Ontario, v.11, n.5, p.183-194, 2019.

PEZZINI, R.V.; CARGNELUTTI FILHO, A.; ALVES, B.M.; FOLLMANN, D.N.; KLEINPAUL, J.A.; WARTHA, C.A.; SILVEIRA, D.L. Models for leaf area estimation in dwarf pigeon pea by leaf dimensions. Bragantia, Campinas, v.77, n.2, p.221-229, 2018.

REIS, A.F.; SCHMIELE, M. Características e potencialidades dos frutos do Cerrado na indústria de alimentos. Brazilian Journal of Food Technology, Campinas, v.22, p.1-12. 2019.

RESSEL, K.A.; RIBEIRO, M.S.L.; REIS, E.F. Desempenho de progênies de diferentes matrizes de cajuzinho-do-cerrado mediante o armazenamento e o peso das núculas. Ciência Rural, Santa Maria, v.45, n.10, p.1782-1787, 2015.

RIBEIRO, J.E.S.; BARBOSA, A.J.S.; ALBUQUERQUE, M.B. Leaf area estimate of Erythroxylum simonis Plowman by linear dimensions. Floresta e Ambiente, Rio de Janeiro, v.25, n.2, p.e20170108, 2018. 
SACHET, M.R.; PENSO, G.A.; PERTILLE, R.H.; GUERREZI, M.T.; CITADIN, I. Estimativa da área foliar de pessegueiro por método não-destrutivo. Ciência Rural, Santa Maria, v.45, n.12, p.2161-2163, 2015.

SANTOS, S.N.; DIGAN, R.C.; AGUILAR, M.A.G.; SOUZA, C.A.S.; PINTO, D.G.; MARINATO, C.S.; ARPINI, T.S. Análise comparativa de métodos de determinação de área foliar em genótipos de cacau. Bioscience Journal, Uberlândia, v.30, n.3, 2014. Supplemento

SANTOS, R. da C. dos; SANTOS JÚNIOR J.E. dos. Divergência genética por análise multivariada de caracteres fenotípicos de Anacardium Humile (St.Hilaire). Revista Ceres, Viçosa, MG, v.62, n.6, p.553-560, 2015.

SANTOS, S.C.; CARVALHO, R.DOS S.; DAVIDE, L.M.C. Genetic Polymorphism among Natural Populations of Anacardium Humile A.ST-HIL. Revista Brasileira de Fruticultura, Jaboticabal, v.42, n.1, 2020.

SILVA, S.F.; CABANEZ, P.A.; MENDONÇA, R.F.; PEREIRA, L.R.; AMARAL, J.A.T. Modelos alométricos para estimativa da área foliar de mangueira pelo método não destrutivo. Revista Agro@ambiente On-line, Roraima, v.9, n.1, p.86-90, 2015.

SILVA-LUZ, C.L.; PIRANI, J.R. Anacardiaceae in lista de espécies da flora do Brasil. Rio de Janeiro: Jardim Botânico do Rio de Janeiro, 2010.
SHI, P.; LIU, M.; YU, X.; GIELIS, J.; RATKOWSKY, D.A. Proportional relationship between leaf area and the product of leaf length and width of four types of special leaf shapes. Forests, Basel, v.10, n.2, p.178, 2019.

TOEBE, M.; CARGNELUTTI FILHO, A.; LOOSE, L.H.; HELDWEIN, A.B.; ZANON, A.J. Leaf area of snap bean (Phaseolus vulgaris L.) according to leaf dimensions. Semina: Ciências Agrárias, Londrina, v.33, n.1, p.24912500, 2012.

TOEBE, M.; SOUZA, R.R.; MELLO, A.C.; MELO, P.J.; SEGATTO, A.; CASTANHA, A.C. Leaf area estimation of squash 'Brasileirinha' by leaf dimensions. Ciência Rural, Santa Maria, v.49, n.4, p.1-11, 2019. VIEIRA JUNIOR, P.A.; NETO, D.D.; CICERO, S.M.; JORGE, L.A.D.C.; MANFRON, P.A.; MARTIN, T.N. Estimativa da área foliar em milho através de análise de imagens. Revista Brasileira de Milho e Sorgo, Sete Lagoas, v.5, n.1, p.58-66, 2006.

ZEIST, A.R.; OLIVEIRA, J.R.F.; LIMA FILHO, R.B.; SILVA, M.L.S.; RESENDE, J.T.V. Comparação de métodos de estimativa de área foliar em morangueiro. Pesquisa Agropecuária Gaúcha, Porto Alegre, v.20, p.33-41, 2014. 